\title{
Üniversite Öğrencilerinin Finansal Okuryazarlık Durumunu Etkileyen Faktörler Üzerine Bir Araştırma: Muğla Sıtkı Koçman Üniversitesi Örneği
}

Filiz YILDIZ CONTUK *

\section{ÖZET}

Küreselleşen ve sinırların kalktı̆̆g dünyada finansal okuryazarlı, bireylerin ekonomik hayatın karmaşıllığına ve belirsizliğine karşı korunmak için ihtiyaç duydukları bilgi ve becerileri sağlar. Günümüz sosyo-ekonomik koşullarında bireylerin finansal okuryazarllk becerilerine sahip olmaları hem finansal problemleri önceden öngörüp çözebilmeleri hem de refah içinde bir hayat sürdürebilmeleri açısından önemlidir. Bu koşullarda gençlerin finansal risk ve firsatların farkında olmaları, bütçelerini doğru yönetebilmeleri, finansal problemlere karşı öngörü gelişstirebilmeleri, finansal bilgi birikimine ulaşmaları ve bunu hayatları boyunca devam ettirebilmeleri, bireylerin ve dolayısıyla toplumun finansal sağllğın geliştirmeye katkı sağlayacaktır. Çalışmada gençlerin almış oldukları eğitimin, finansal bilgi birikimlerine hangi düzeyde katkı sağladı̆̆ı belirlenmeye çalışılmıştır. Bu amaçla da Muğla Sitkı Koçman Üniversitesi İktisadi ve İdari Bilimler Fakültesi İsletme bölümünde okuyan ögrrencilerin finansal okuryazarlı durumunu etkileyen faktörler incelenmiştir. Analizde Ki-kare test istatistiği kullanılmıştır. Sonuçlar, ögrrencilerin büyük çoğunluğunun temel düzeyde finans bilgisine sahip olduğu ancak ileri düzeyde finans bilgilerinin yetersiz olduğunu göstermektedir. Bununla birlikte, ögrencilerin genel finans bilgilerinin demografik ve eğitimsel özelliklerinden bazıları tarafindan etkilendiği belirlenmiştir.

Anahtar Kelimeler: Finansal Okuryazarlık, Finansal Bilgi, Üniversite Öğrencileri.

JEL Sinıflandirmasi: A22,D14,G10.

\section{A Study of the Factors Influencing the Financial Literacy of University Students:} The case of Muğla Sıtkı Koçman University

\section{ABSTRACT}

Financial literacy provides the knowledge and skills that individuals need in order to protect themselves against the complexity and uncertainty of economic life in a globalized and borderless world. In today's socioeconomic conditions, it is important for individuals to be equipped with financial literacy skills, both to anticipate and to solve financial problems, and to live well. Young people's awareness of financial risks and opportunities and budget management; their foresight regardingfinancial problems;and financial knowledge and its sustainability throughout their lives improve the financial health of individuals, and thus, of society. This study aimed to determine the contribution levelofyoung people's education to their financial knowledge. For this purpose, the factors influencing the financial literacy of the students from the Department of Management in the Faculty of Economics and Administrative Sciences of Muğla Sitkı Koçman University were investigated. Chisquare test statistic was used in the analysis. The results show that the vast majority of students have a basic level of financial knowledge, but that advanced financial information is inadequate. However, it has been determined that students are influenced by some of the demographic and educational characteristics of the general financial information.

Keywords: Financial Literacy, Financial Knowledge, University Students.

Jel Classification: A22,D14,G10.

\footnotetext{
* Öğr. Gör. Dr. Filiz Yıldız Contuk, Muğla Sttkı Koçman Üniversitesi, Fethiye A.S.M.K. Meslek Yüksekokulu, fcontuk@mu.edu.tr
} 


\section{GíRiş}

Son yıllarda birey, toplum ve ülke ekseninde ele alınan bir konu haline gelen finansal okuryazarlık kavramı para yönetimi konusunda bilgili ve akılcı karar verebilme becerisi olarak tanımlanabilir(Cihangir ve Ergin, 2015:493). Diğer bir deyişle finansal okuryazarlık, tüketicinin paranın kullanımında ve yönetiminde bilgiyle değerlendirme yapmasını ve finansal araçların seçiminde etkili ve rasyonel kararlar verebilmesini sağlayan yeterlilik düzeyidir. Başka bir ifade ile bireylerin gelirlerini, birikim ve yatırımlarını akıllıca değerlendirme ve bütçelerini doğru yönetebilme yetkinliğine sahip olabilmesi şeklinde tanımlanmaktadır (TEB,2012:3).

Genç nüfusun daha yoğun olduğu ülkemizde gelir ve istihdam rakamlarına bakıldığında, gençlerin finansal firsatlar ve bilgi kaynaklarından yeterince faydalanmadığı ve bu konuda sıkıntılar yaşadığı görülmektedir (www.paramiyonetebiliyorum.net). Finansal bilgi düzeyleri yetersiz olan genç neslin finansal okuryazarlık durumu eğitimciler, bankalar ve ekonomistler gibi birçok farklı grup tarafından sıkça gündeme getirilmekte ve konu ile ilgili endişeleri arttırmaktadır. Ebeveynleriyle birlikte yaşayan genç bireyler için finansal karar alma yükümlülügü hayatlarının belirli aşamalarına kadar karşılarına çıkmadığı için, üniversite hayatlarına başladıklarında bir bakıma finansal kararlarını da kendi başlarına almak zorunda kalmaktadırlar. Bu nedenle yeterli düzeyde finansal okuryazarlık bilgisine sahip olmaları bu noktada önem arz etmektedir (Kılıç vd., 2015:130). Gençlerin kendi bütçelerini yönetmeyi öğrenmesiyle birlikte sağlıklı bir finansal gelecek oluşturmaları sağlanarak ve uzun vadede finansal okuryazarlık düzeyi yüksek nesiller oluşturularak sürdürülebilir kalkınma sürecine katkıda bulunulabilir. Bu doğrultuda, ekonomik istikrar ve sürdürülebilirlik için finansal okuryazarlık büyük önem taşımaktadır(www.paramiyonetebiliyorum.net). Öte yandan, öğrenciler para kazanmaya başladıklarında yatırım kararını almak için kişisel finans konularında güçlü finansal okuryazarlığa sahip olmalıdırlar. Buna ek olarak, kendi finansal kararlarını almalı ve ihtiyaçları doğrultusunda yönetmelidirler. Genç nesil, özellikle de öğrenciler finansal kararlarını doğru vermede yoksundurlar. Tasarruf etmek yerine harcamayı severler. Geleceği akılda tutarak öğrencilerin tasarruf alışkanlığı geliştirmeleri gerekir. Ayrıca bankalar tarafindan sağlanan çeşitli finansal hizmetler ve tesislerden haberdar olmaları, onların daha güvenli ve daha iyi bir gelecek planlamaları ve sağlam kararlar vermelerini etkileyecektir(Rizwan vd,2015:730).

Üniversitede okuyan öğrencilerin büyük çoğunluğu ailelerinden ayrı yaşarlar ve bu gençlerde tasarruf, harcama ve yatırım bilincinin oluşması ve güçlendirilmesi büyük önem arz etmektedir. Bu yüzden öğrencilerin finansal okuryazarlık düzeylerini değerlendirerek, onların finansal alışkanlıkları ve davranışları hakkında bilgi edinebiliriz. Bu amaçla çalışmada 2016 yılı itibariyle Muğla Sıtkı Koçman Üniversitesi İktisadi ve İdari Bilimler Fakültesi’nde okuyan İşletme bölümü öğrencilerinin üniversitede almış oldukları lisans eğitiminin finansal okuryazarlıklarına olan etkisi incelenmiştir.

\section{LITERATÜR}

Finansal okuryazarlık konunda literatürde çok fazla çalışma bulunmaktadır ve bu çalışmalarda bireylerin finansal okuryazarlık durumları farklı açılardan ele alınmıştır. Çalışmamızın bu bölümünde bunlara kısaca değinilmiştir. 
Chen ve Volpe tarafından (1998) 924 üniversite öğrencisinin kişisel finansal okuryazarlıkları üzerine yapılan bir araştırmada, katılımcıların soruların yaklaşık\% 53'ünü doğru olarak cevaplandıkları belirlenmiştir. Öğrencilerin kişisel finans bilgilerinin yetersiz olduğu sonucuna ulaşılmış ve yeterli bilgiye sahip olmayan bu bireylerin finansal kararlarını almada yanlış kararlar verme eğiliminin yüksek olduğu belirlenmiştir.

Worthington (2006), Avusturalya da yetişkinlerin finansal okuryazarlılığını belirlemek için Logit modelerini kullanarak yaptığı çalışmasında cinsiyet, yaş, etnik köken, meslek, gelir, tasarruf ve borç faktörlerini incelemiştir. Sonuç olarak ise finansal okuryazarlık oranının 5060 yaş grubu, meslek sahipleri, çiftlik sahipleri ve üniversite mezunları arasında yüksek düzeyde olduğunu belirlemiş; işsizler, kadınlar, eğitim seviyesi düşük düzeyde olanlar ve İngilizce bilmeyenlerde ise bu oranın düşük olduğunu tespit etmiştir.

Lusardi (2008), ABD'de belirli demografik özellikteki grupların(Afro-Amerikan, İspanyollar, kadınlar ve düşük eğitimli kişiler) finansal okuryazarlığını ölçmeye yönelik yaptığı çalışmada, finansal okuryazarlık seviyesinin oldukça düşük olduğunu tespit etmiştir. Emeklilik, borsaya katılımın az olması ve uygun olmayan koşullarda borçlanmanın planlamasındaki başarısızlığın nedenini, temel finansal kavramlar hakkındaki bilgi eksikliğine bağlamıştır. Bunun içinde finansal eğitim programlarının bireylerin tasarruf davranışını ve finansal karar alma sürecini geliştirebileceğini ve bu eğitim programlarının etkinliğinin arttırılması gerektiğini ileri sürmüştür.

Jorgensen ve Savla (2010) tarafından yapılan bir çalışmada genç yetişkinlerin finansal okuryazarlık seviyesi üzerinde ebeveynlerin etkisi araştırılmıştır. Yapısal eşitlik modelinin uygulandığı çalışmada 420 üniversite öğrencisi ankete dahil edilmiştir. Çalışma sonuçlarına göre ailelerin gençlerin finansal tutumları üzerinde doğrudan bir etkisi varken, finansal bilgileri üzerinde bir etkisinin olmadığını tespit etmişlerdir. Finansal davranışlarında ise dolaylı bir etkilerinin olduğunu belirlemişlerdir.

Temizel ve Bayram (2011), Anadolu Üniversitesi İktisadi ve İdari Bilimler Fakültesi'nde öğrenim gören öğrencilerin temel düzeyde finansal okuryazarlık düzeyini belirlemek amacıyla bir çalışma yapmışlardır. Çalışma sonucunda öğrencilerin finansal durumlarını yönetmede kendilerini olduğundan daha başarılı olarak algıladıklarını belirlemişlerdir. Ayrıca öğrencilerin ekonomik ve finansal gelişmeleri izlediği başlıca kaynakların televizyon ve internet olduğu, kitap ve dergileri ise çok fazla kullanmadıkları sonucuna ulaşmışlardır.

2013 de Shaari vd. tarafından Malezya üniversitesinde 384 öğrencinin yaş, cinsiyet, sınıf, alınan eğitim ve harcama alışkanlıklarının finansal okuryazarlık düzeyleri üzerindeki etkisi çoklu doğrusal regresyon analizi yapılarak belirlenmeye çalışılmıştır. Çalışma sonucunda harcama alışkanlığı ve sınıf değişkeninin finansal okuryazarlık üzerinde pozitif ve önemli bir etkisi tespit edilmişken, yaş ve cinsiyetin finansal okuryazarlık üzerine etkisi negatif olarak bulunmuştur.

2013 yılında Malezya da Mahdzan ve Tabiani tarafından yapılan diğer bir çalışmada Lusardi'nin (2008) anket formatı temel alınmıştır. Probit regresyon yapılan çalışma sonucunda finansal okuryazarlık düzeyinin bireysel tasarruf üzerinde pozitif ve önemli bir etkisi olduğu tespit edilmiştir. Çalışma önerisi olarak ulusal düzeyde tasarruf seviyesinin 
artması için politika yapıcıların hane halklarına eğitim vermelerinin faydalı olabileceği vurgulanmıştır.

Adeleke (2013), üniversite öğrencilerinin cinsiyetlerinin finansal okuryazarlık düzeylerini etkileyip etkilemediği araştırmak için, ABD'de Oklahoma Eyalet Üniversitesi'nden 100 katılımcıya anket uygulamıştır. Varyans analizi yapılan çalışma sonuçlarına göre, üniversite öğrencilerinin cinsiyeti ile finansal okuryazarlık düzeyi arasında bir ilişki bulunamamıştır. Ancak korelasyon analizi sonuçlarında katılımcıların okulda geçirdikleri yıl ve yaşları ile finansal okuryazarlık düzeyleri arasında anlamlı ilişkiler bulunmuştur.

Aggarwal ve Gupta (2014) cinsiyet, eğitim ve nitelik gibi demografik faktörlerin finansal okuryazarlık üzerindeki etkisini incelemiş̧lerdir. 148 katılımcının cevapladığı anket sonuçlarına göre erkeklerin kadınlara göre daha fazla finansal bilgiye sahip oldukları ve eğitim seviyesinin genel finansal bilinç üzerindeki etkisinin olumlu olduğu kanısına ulaşmışlardır.

Er vd. (2014) tarafindan Türkiye'de faaliyet gösteren 5 ayrı devlet üniversitesinde öğrenim gören İktisadi ve İdari Bilimler Fakültesi öğrencileri ile Mühendislik Fakültesi öğrencilerinin finansal okuryazarlıklarını karşılaştırılmıştır. 824 öğrencinin katıldığ sonuçlarına göre üniversite ögrencilerinin $\% 31,7$ ' sinin yüksek, $\% 30,1^{\prime}$ inin orta, \%16 sının ise düşük finansal okuryazarlığa sahip olduğu belirlenmiştir. Üniversite Öğrencilerinin eğitim alanları (sayısal: mühendislik fakültesi ve sözel: iktisadi ve idari bilimler fakültesi) ile finansal okuryazarlık düzeyleri arasında da anlamlı ilişki tespit edilmiştir.

Ergün vd. tarafından 2014 yılında yapılan çalışmada ise Osmaniye Korkut Ata Üniversitesi, İktisadi ve İdari Bilimler Fakültesi, İşletme bölümü öğrencilerinin finansal okuryazarlıkları ile demografik özellikleri arasında herhangi bir ilişkinin olup olmadığı araştırılmıştır. Çalışma sonuçlarına göre öğrencilerin yalnızca temel düzeyde finansal okuryazar oldukları tespit edilmiştir.

Kılıç vd. (2015) tarafından üniversite öğrencilerinin finansal okuryazarlık düzeyinin belirlenmesi amacıyla Gaziantep Üniversitesi'nde 480 öğrenciye bir anket uygulamışlardır. Öğrencilerin demografik özelliklerinin etkisinin incelendiği çalışma sonuçlarına göre finansal okuryazarlık genel başarı düzeyi \%48 olarak bulunmuştur. Erkek öğrencilerin finansal okuryazarlık düzeyinin bayan öğrencilere göre daha yüksek olduğunu belirlemişlerdir.

Çam ve Barut (2015) üniversite öğrencilerinin finansal okuryazarlık düzeyini ve davranışlarını tespit etmek amacıyla Gümüşhane Üniversitesi önlisans programlarında kayıtlı 400 öğrenciye anket uygulamışlardır. Çalışmada çoklu regresyon analizini kullanarak, özellikle öğrencilerin parayı harcama ve yönetme başarısını etkileyen unsurları belirlemeye çalışmışlardır. Çalışma sonucunda, öğrencilerin finansal okuryazar olmadıkları ve temel finansal kavramlar hakkında çok az bilgiye sahip olduklarını belirlemişlerdir.

2015 yılında Cihangir ve Ergin tarafından yapılan bir çalışmada Osmaniye ilinde yaşayan halkın bazı demografik değişkenler açısından temel finansal okuryazarlık düzeyi incelenmiş ve Türkiye sonuçları ile karşılaştırılmıştır. Çalışmada OECD’nin finansal okuryazarlığı temel düzeyde ölçmek için farklı ülkelerde uygulamış olduğu çekirdek anket 
kullanılmıştır. Sonuç olarak ankete katılanların en yüksek bilgiye sahip olduğu konu ödenen faiz bilgisi iken, en az bilgi sahibi olduğu konu ise çeşitlendirme bilgisi olduğu tespit edilmiştir.

Potrich vd. (2015) tarafından yapılan bir çalışmada bireylerin finansal okuryazarlık düzeyini sosyoekonomik ve demografik değişkenlerle açıklayan bir model geliştirilmiştir. Örneklem, Brezilya'da yaşayan 1.400 katılımcidan oluşturulmuştur ve veri analizi, betimsel istatistikler ve çok değişkenli analiz teknikleri kullanmışlardır. Katılımcıların finansal okuryazarlık düzeyi; finansal tutum, finansal davranış ve finansal bilgi açısından incelenmiştir. Sonuç olarak katılımcıların çoğunun (\% 67.1) finansal okuryazarlık seviyesinin düşük olduğu belirlenmiştir.

Albeerdy ve Gharleghi (2015), Malezya'daki üniversite öğrencileri arasında finansal okuryazarlığı etkileyen faktörleri araştırmak için 105 adet anket yapmışlardır. Finansal okuryazarlıktaki farklı değişkenlerin birbiriyle olan ilişkisini belirlemek için Pearson Korelasyon analizi ve çoklu regresyon tablolarını kullanmışlar ve sonuç olarak, eğitim durumu ile finansal okuryazarlık arasında anlamlı bir ilişki olduğunu belirlemişlerdir. Finansal sosyalleşme aracıları ile finansal okuryazarlık arasında ise hiçbir ilişki bulunamamıştır.

Thapa ve Nepal (2015), 436 üniversite öğrencisinin demografik, eğitimsel ve kişilik özelliklerinin finansal okuryazarlık üzerindeki etkisini ANOVA, ortalama ve lojistik regresyon testlerini kullanarak araştırmışlardır. Sonuçlar, öğrencilerin çoğunun temel düzeyde finansal bilgiye sahip olduğunu ancak kredi, vergi, hisse senedi piyasası, finansal tablo ve sigorta kavramlarında yetersiz olduğunu tespit etmişlerdir. Bununla birlikte, öğrencilerin genel finansal bilgilerinin demografik, eğitimsel ve kişilik özelliklerinden bazıları tarafından etkilendiğini belirlemişlerdir.

\section{VERI SETİ VE YÖNTEM}

$\mathrm{Bu}$ çalışmada, finansla ilgili dersler alan işletme bölümü öğrencilerinin finansal okuryazarlık düzeylerinin belirlenmesi ve demografik değişkenlerle finansal okuryazarlık başarı düzeyleri arasında bir ilişki olup olmadığının belirlenmesi amaçlanmıştır. Bu amaçla çalışmada Muğla Sıtkı Koçman Üniversitesi İktisadi ve İdari Bilimler Fakültesi İşletme Bölümü öğrencilerine 2015-2016 Bahar yarıyılında bir anket yapılmıştır. Fakültede işletme bölümüne kayıtlı 1472 öğrenciden, mevcut durumda final sınavlarına katılan 327 öğrenciye (Kayıp verisi olan 7 anket analize dahil edilmemiştir) tesadüfî olmayan örnekleme yöntemlerinden kolayda örnekleme yöntemiyle anket uygulanmıştır ve araştırmaya katılan bireyler, ana kütlenin \% 22'sini oluşturmaktadır. Sonuçlar SPSS 22.0 istatistik paket programı kullanılarak analiz edilmiştir. Çalışmada parametrik olmayan testlerden ki-kare test istatistiği uygulanmıştır.

Ki-kare dağılımı, genellikle iki bağımsız niteliksel kriteri test etmek için kullanılır. Sıfır hipotezi $\left(\mathrm{H}_{0}\right)$, iki kriterin bağımsız olduğunu; araştırma hipotezi $\left(\mathrm{H}_{\mathrm{A}}\right)$ ise, iki kriterin arasında ilişki olduğunu ifade eder (Güngör ve Bulut, 2008:84). Bu amaçla çalışmamızda $\mathrm{H}_{0}$ hipotezine alternatif olarak demografik değişkenlerle ilgili aşağıdaki hipotezler oluşturulmuştur. 
Hipotezler;

$\mathrm{H}_{1}$ : Bayan öğrenciler ile erkek öğrencilerin finansal okuryazarlık başarı düzeyleri arasında bir farklılık vardır.

$\mathrm{H}_{2}$ : Öğrencilerin okumuş oldukları sınıf ile finansal okuryazarlık başarı düzeyleri arasında bir farklılık vardır

$\mathrm{H}_{3}$ : Öğrencilerin eğitim şekli ile finansal okuryazarlık başarı düzeyleri arasında bir farkl1lık vardır

$\mathrm{H}_{4}$ : Öğrencilerin ortalama genel başarı düzeyleri ile finansal okuryazarlık başarı düzeyleri arasında bir ilişki vardır

$\mathrm{H}_{5}$ : Öğrencilerin anne-baba eğitim düzeyi ile finansal okuryazarlık başarı düzeyleri arasında bir farklılık vardır

$\mathrm{H}_{6}$ : Öğrencilerin hane geliri ile finansal okuryazarlık başarı düzeyleri arasında anlamlı bir farklılık vardır.

$\mathrm{H}_{7}$ : Öğrencilerin yaşları ile finansal okuryazarlık başarı düzeyleri arasında anlamlı bir farklılık vardır.

\subsection{Araştırma Bulguları}

Çalışmada üniversite öğrencileri arasındaki finansal okuryazarlık düzeyi, temelden ileri finansman düzeyine doğru 10 soru sorularak analiz edilmiştir. İşletme bölümünü öğrencileri üzerine anket çalışması yapılmış ve toplanan veriler ki-kare test istatistiği kullanılarak analiz edilmiştir.

Araştırma sonucunda elde edilen tanımlayıcı istatistikler ve ki-kare testi sonucunda elde edilen bulgular tablolarda verilmiştir. İlk olarak anketten elde edilen tanımlayıcı istatistik sonuçları Tablo 1'deki şekliyle aşağıda sunulmuştur.

Tablo 1. Ankete Katılan Öğrencilerin Demografik Dağılımı

\begin{tabular}{|c|c|c|c|c|c|c|c|}
\hline Değişkenler & Gruplar & $\begin{array}{l}\text { Siklık } \\
\text { (Kişi) } \\
\end{array}$ & $\begin{array}{l}\text { Yüzde } \\
(\%)\end{array}$ & Değişkenler & Gruplar & \begin{tabular}{|l} 
S1klık \\
(Kişi) \\
\end{tabular} & \begin{tabular}{|l}
$\begin{array}{l}\text { Yüzde } \\
(\%)\end{array}$ \\
\end{tabular} \\
\hline \multirow{3}{*}{ Cinsiyet } & Kadın & 146 & $45,6 \%$ & \multirow{6}{*}{$\begin{array}{c}\text { Anne } \\
\text { Eğitim } \\
\text { Durumu }\end{array}$} & okuma yazma bilmiyor & 16 & $5,0 \%$ \\
\hline & Erkek & 174 & $54,4 \%$ & & ilkokul & 138 & $43,1 \%$ \\
\hline & Toplam & 320 & $100,0 \%$ & & ortaokul & 59 & $18,4 \%$ \\
\hline & & & & & lise & 82 & $25,6 \%$ \\
\hline \multirow{5}{*}{ Sinif } & 1 & 84 & $26,3 \%$ & & üniversite-Lisansüstü & 25 & $7,8 \%$ \\
\hline & 2 & 77 & $24,1 \%$ & & Toplam & 320 & $100,0 \%$ \\
\hline & 3 & 80 & $25,0 \%$ & & & & \\
\hline & 4 & 79 & $24,6 \%$ & \multirow{3}{*}{$\begin{array}{c}\text { Baba } \\
\text { Eğitim } \\
\text { Durumu }\end{array}$} & okuma yazma bilmiyor & 2 &, $6 \%$ \\
\hline & Toplam & 320 & $100,0 \%$ & & ilkokul & 88 & $27,5 \%$ \\
\hline & & & & & ortaokul & 90 & $28,1 \%$ \\
\hline
\end{tabular}




\begin{tabular}{|c|c|c|c|c|c|c|c|}
\hline \multirow{3}{*}{ Eğitim Şekli } & Birinci öğretim & 151 & $47,2 \%$ & & lise & 92 & $28,8 \%$ \\
\hline & İkinci öğretim & 169 & $52,8 \%$ & & üniversite-Lisansüstü & 48 & $15,0 \%$ \\
\hline & Toplam & 320 & $100,0 \%$ & & Toplam & 320 & $100,0 \%$ \\
\hline \multirow{5}{*}{$\begin{array}{l}\text { Genel Not } \\
\text { Ortalamas1 }\end{array}$} & 2.00 veya alt1 & 77 & $24,1 \%$ & \multirow{6}{*}{$\begin{array}{c}\text { Aylık Hane } \\
\text { Geliri }\end{array}$} & 1000 TL- Daha az & 33 & $10,3 \%$ \\
\hline & $2.01-2.75$ & 151 & $47,2 \%$ & & 1001 TL-2000 TL & 118 & $36,9 \%$ \\
\hline & $2.76-3.25$ & 69 & $21,6 \%$ & & 2001 TL-3000TL & 81 & $25,3 \%$ \\
\hline & $3.26-4.00$ & 23 & $7,2 \%$ & & 3001 TL-4000 TL & 52 & $16,3 \%$ \\
\hline & Toplam & 320 & $100,0 \%$ & & 4000 TL-Daha çok & 36 & $11,3 \%$ \\
\hline & & & & & Toplam & 320 & $100,0 \%$ \\
\hline \multirow{3}{*}{ Yaş } & $18-20$ & 99 & $30,90 \%$ & & & & \\
\hline & $21-22$ & 119 & $37,20 \%$ & & & & \\
\hline & 23 ve üzeri & 102 & $31,90 \%$ & & & & \\
\hline
\end{tabular}

Tablo 1'e göre araştırmaya katılan öğrencilerin çoğunluğunu $(\% 54,4)$ erkekler oluşturmaktadır. Okudukları sınıfa göre değerlendirildiğinde öğrencilerin birbirine yakın dağılım gösterdiği görülmektedir. Ankete katılan öğrencilerin \%52,8 ini ikinci öğretim öğrencileri oluşturmaktadır. Ayrıca ankete katılan öğrencilerin yarısının $(\% 47,2)$ genel not ortalamasının 2.01-2.75 arasında olduğu görülmektedir. Araştırmaya katılan öğrencilerin \%37, 2 sinin 21-22 yaş aralığında olduğu ve genel olarak yaş aralığı yüzdelerinin birbirine yakın olduğu söylenebilir. Ankete katılan öğrencilerin büyük çoğunluğunun anne eğitim düzeyi ilkokul iken, baba eğitim düzeyi ortaokul ve lise düzeyinde ağırlık göstermektedir. Son olarak katılımcıların büyük çoğunluğunun ailelerinin gelir düzeyinin askeri ücret düzeyinde (1000-2000 TL) dağılım gösterdiği söylenebilir.

Ankete katılan öğrencilerin anket sorularına vermiş oldukları yanıtlar non-paremetrik testlerden biri olan ki-kare testiyle analiz edilmiş ve her bir sorudan elde edilen sonuçlar sırasıyla aşağıdaki tablolarda sunulmuştur.

1-100 TL'nizin olduğunu ve faiz oranının yıllık \%2 olduğunu varsayınız. Bu şartlar altında paranızı bankaya yatırmanız durumunda 5 yıl sonra paranızın tutarı ne kadar olur?" sorusuna verilen cevapların analizi aşağıdaki tabloda özetlenmiştir.

Tablo 2. Temel Düzeyde Faiz Bilgisi

\begin{tabular}{|c|c|c|c|c|c|c|c|}
\hline & & \multicolumn{2}{|c|}{$\begin{array}{c}\text { Doğru Cevap } \\
\text { Verenler }\end{array}$} & \multicolumn{2}{|c|}{$\begin{array}{c}\text { Yanlış Cevap } \\
\text { Verenler } \\
\end{array}$} & \multirow[b]{2}{*}{$X^{2}$} & \multirow[b]{2}{*}{$\mathrm{P}$} \\
\hline Değişkenler & Gruplar & \begin{tabular}{|l} 
Siklık \\
(Kişi) \\
\end{tabular} & \begin{tabular}{|l|}
$\begin{array}{l}\text { Yüzde } \\
(\%)\end{array}$ \\
\end{tabular} & \begin{tabular}{|l|l} 
Siklık \\
(Kişi)
\end{tabular} & \begin{tabular}{|l|}
$\begin{array}{l}\text { Yüzde } \\
(\%)\end{array}$ \\
\end{tabular} & & \\
\hline \multirow{2}{*}{ Cinsiyet } & Kadın & \begin{tabular}{|r|}
128 \\
\end{tabular} & $87,7 \%$ & 18 & $12,3 \%$ & \multirow{2}{*}{0,534} & \multirow{2}{*}{0,465} \\
\hline & Erkek & 157 & $90,2 \%$ & 17 & $9,8 \%$ & & \\
\hline \multirow{2}{*}{ Sinif } & Birinci sinıf & 71 & $84,5 \%$ & 13 & $15,5 \%$ & \multirow{2}{*}{8,401} & \multirow{2}{*}{0,038} \\
\hline & İkinci Sınıf & 66 & $85,7 \%$ & 11 & $14,3 \%$ & & \\
\hline
\end{tabular}




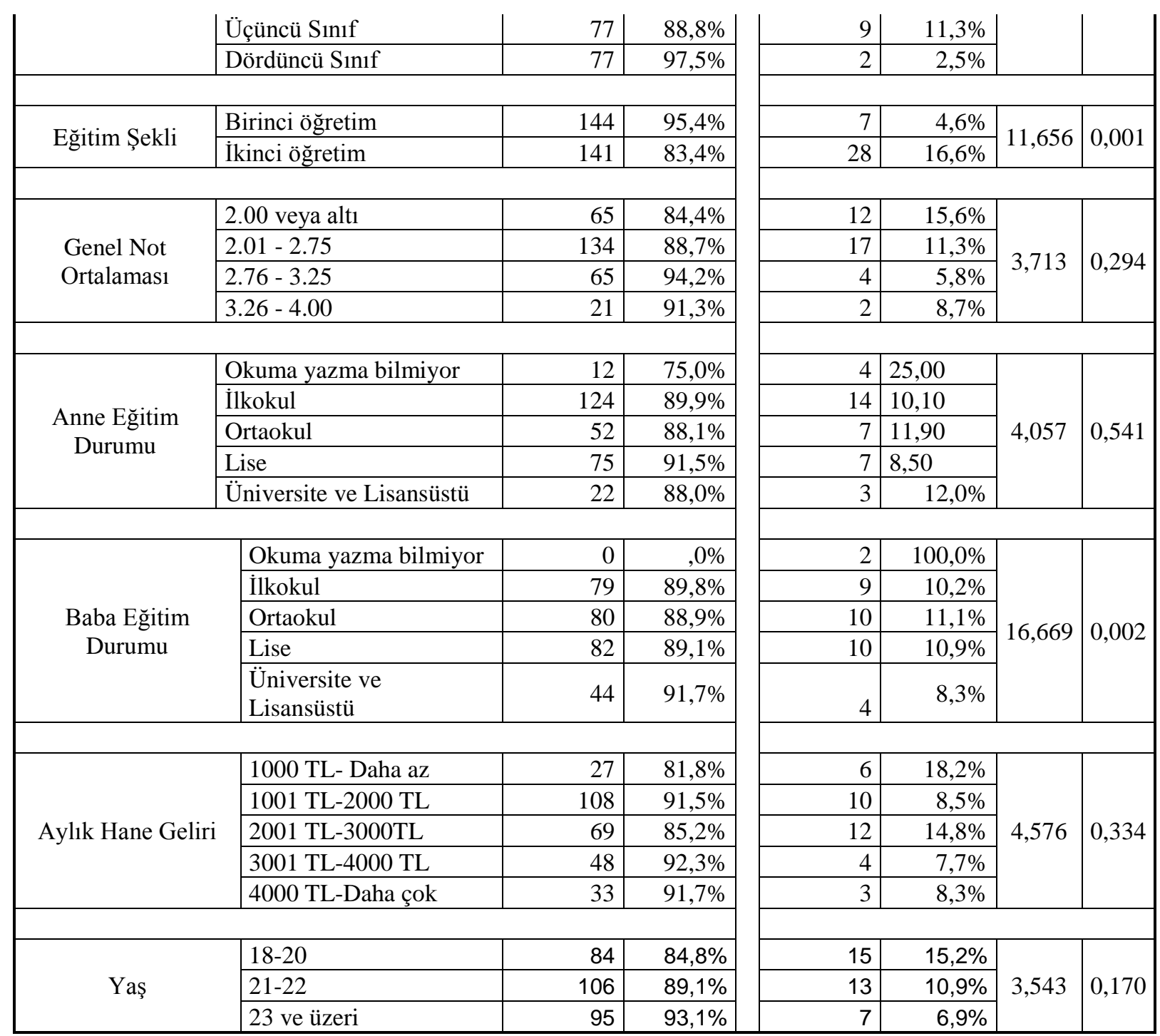

Temel düzeyde faiz bilgisinin belirlenmeye çalışıldığı bu soruda, öğrencilerin büyük çoğunluğunun soruya doğru cevap verdikleri görülmektedir ve bu durumda öğrencilerin temel düzeyde faiz bilgisine sahip oldukları söylenebilir. Tablo 2'ye bakıldığında öğrencilerin okudukları sınıf, eğitim şekli ve baba eğitim durumu değişkenleri ile finansal okuryazarlık başarı düzeyleri arasında anlamlı bir faklılık olduğu görülmektedir. Okudukları sınıf bazında değerlendirildiğinde, almış oldukları eğitimin başarı düzeylerine katkı sağladığı görülmektedir. Ayrıca normal öğretimde okuyan öğrencilerin daha başarılı oldukları görülmektedir. Babanın eğitim düzeyinin de öğrencilerin başarısında etkili olduğunu söylemek mümkündür.

Soru 2- Hesabınızda $100 \mathrm{TL}$ ve uygulanan faiz oranın yıllık \%1 olduğunu, bunun yanında yıllık enflasyon oranının $\% 2$ olduğunu düşünün. 1 yıl sonra hesabınızdaki para ile ne kadar harcama yapabilirsiniz? 
Tablo 3. Temel Düzeyde Enflasyon Bilgisi

\begin{tabular}{|c|c|c|c|c|c|c|c|}
\hline \multirow{2}{*}{ Değişkenler } & \multirow[b]{2}{*}{ Gruplar } & \multicolumn{2}{|c|}{ Doğru Cevap Verenler } & \multicolumn{2}{|c|}{ Yanlış Cevap Verenler } & \multirow[b]{2}{*}{$X^{2}$} & \multirow[b]{2}{*}{$\mathrm{P}$} \\
\hline & & $\begin{array}{l}\text { S1klık } \\
\text { (Kişi) }\end{array}$ & $\begin{array}{l}\text { Yüzde } \\
\text { (\%) }\end{array}$ & $\begin{array}{l}\text { Siklık } \\
\text { (Kiși) }\end{array}$ & $\begin{array}{l}\text { Yüzde } \\
(\%)\end{array}$ & & \\
\hline \multirow{2}{*}{ Cinsiyet } & Kadın & 85 & $58,2 \%$ & 61 & $41,8 \%$ & \multirow{2}{*}{5,963} & \multirow{2}{*}{0,015} \\
\hline & Erkek & 124 & $71,3 \%$ & 50 & $28,7 \%$ & & \\
\hline \multirow{4}{*}{ Sinif } & Birinci sinıf & 47 & $56,0 \%$ & 37 & $44,0 \%$ & \multirow{4}{*}{6,052} & \multirow{4}{*}{0,109} \\
\hline & İkinci Sınıf & 49 & $63,6 \%$ & 28 & $36,4 \%$ & & \\
\hline & Üçüncü Sinıf & 55 & $68,8 \%$ & 25 & $31,3 \%$ & & \\
\hline & Dördüncü Sınıf & 58 & $73,4 \%$ & 21 & $26,6 \%$ & & \\
\hline \multirow{3}{*}{ Eğitim Şekli } & Birinci öŏretim & 103 & $682 \%$ & 48 & $2180 \%$ & \multirow{3}{*}{1,061} & \multirow{3}{*}{0,303} \\
\hline & Dimcr ogretm & 103 & $68, \angle \%$ & 40 & $31,8 \%$ & & \\
\hline & İkinci öğretim & 106 & $62,7 \%$ & 63 & $37,3 \%$ & & \\
\hline \multirow{4}{*}{$\begin{array}{l}\text { Genel Not } \\
\text { Ortalamas1 }\end{array}$} & 2.00 veya altı & 53 & $68,8 \%$ & 24 & $31,2 \%$ & \multirow{4}{*}{5,980} & \multirow{4}{*}{0,113} \\
\hline & $2.01-2.75$ & 91 & $60,3 \%$ & 60 & $39,7 \%$ & & \\
\hline & $2.76-3.25$ & 52 & $75,4 \%$ & 17 & $24,6 \%$ & & \\
\hline & $3.26-4.00$ & 13 & $56,5 \%$ & 10 & $43,5 \%$ & & \\
\hline \multirow{5}{*}{$\begin{array}{l}\text { Anne Eğitim } \\
\text { Durumu }\end{array}$} & $\begin{array}{l}\text { Okuma yazma } \\
\text { bilmiyor }\end{array}$ & 10 & $62,5 \%$ & 6 & $37,5 \%$ & \multirow{5}{*}{2,167} & \multirow{5}{*}{0,705} \\
\hline & İlkokul & 94 & $68,1 \%$ & 44 & $31,9 \%$ & & \\
\hline & Ortaokul & 38 & $64,4 \%$ & 21 & $35,6 \%$ & & \\
\hline & Lise & 49 & $59,8 \%$ & 33 & $40,2 \%$ & & \\
\hline & $\begin{array}{l}\text { Üniversite ve } \\
\text { Lisansüstü }\end{array}$ & 18 & $72,0 \%$ & 7 & $28,0 \%$ & & \\
\hline & & & & & & & \\
\hline \multirow{5}{*}{$\begin{array}{l}\text { Baba Eğitim } \\
\text { Durumu }\end{array}$} & $\begin{array}{l}\text { Okuma yazma } \\
\text { bilmiyor }\end{array}$ & 1 & $50,0 \%$ & 1 & $50,0 \%$ & \multirow{5}{*}{0,890} & \multirow{5}{*}{0,926} \\
\hline & İlkokul & 58 & $65,9 \%$ & 30 & $34,1 \%$ & & \\
\hline & Ortaokul & 56 & $62,2 \%$ & 34 & $37,8 \%$ & & \\
\hline & Lise & 61 & $66,3 \%$ & 31 & $33,7 \%$ & & \\
\hline & $\begin{array}{l}\text { Üniversite ve } \\
\text { Lisansüstü }\end{array}$ & 33 & $68,8 \%$ & 15 & $31,3 \%$ & & \\
\hline & & & & & & & \\
\hline \multirow{5}{*}{ Aylık Hane Geliri } & 1000 TL- Daha az & 23 & $69,7 \%$ & 10 & $30,3 \%$ & \multirow{5}{*}{1,783} & \multirow{5}{*}{0,776} \\
\hline & 1001 TL-2000 TL & 74 & $62,7 \%$ & 44 & $37,3 \%$ & & \\
\hline & 2001 TL-3000TL & 54 & $66,7 \%$ & 27 & $33,3 \%$ & & \\
\hline & 3001 TL-4000 TL & 32 & $61,5 \%$ & 20 & $38,5 \%$ & & \\
\hline & 4000 TL-Daha çok & 26 & $72,2 \%$ & 10 & $27,8 \%$ & & \\
\hline \multirow{3}{*}{ Yaş } & $18-20$ & 55 & $55,6 \%$ & 44 & $44,4 \%$ & & \\
\hline & $21-22$ & 81 & $68,1 \%$ & 38 & $31,9 \%$ & 6,321 & 0,042 \\
\hline & 23 ve üzeri & 73 & $71,6 \%$ & 29 & $28,4 \%$ & & \\
\hline
\end{tabular}

Tablo 3'de öğrencilerin temel enflasyon bilgisi değerlendirilmiştir. Cinsiyet ve yaş değişkenleri ile öğrencilerin finansal okuryazarlık başarı düzeyleri arasında istatistiksel olarak anlamlı bir ilişki olduğu görülmektedir. Erkek öğrencilerin kız öğrencilere göre temel enflasyon konusunda daha bilgili oldukları ve öğrencilerin yaşları ilerledikçe bilgilerinin daha 
da arttığı söylenebilir. Genel olarak bakıldığında öğrencilerin \%65,3 ünün soruya doğru cevap verdiği görülmektedir. Yani öğrencilerin temel düzeyde enflasyon bilgisine sahip olduğunu söylemek mümkündür.

Soru 3- Eğer birisi borsada A şirketinin hisse senedini satın alırsa ;

A-B şirketinin bir kısmına sahip olur.

B-B şirketine borç para vermiş olur.

C-B şirketinin borçlarından sorumlu olmuş olur.

D-Yukarıdakilerden hiçbiri

E-Bilmiyorum

Tablo 4. Temel Düzeyde Yatırım Bilgisi

\begin{tabular}{|c|c|c|c|c|c|c|c|}
\hline \multirow[b]{2}{*}{ Değişkenler } & \multirow[b]{2}{*}{ Gruplar } & \multicolumn{2}{|c|}{ Doğru Cevap Verenler } & \multicolumn{2}{|c|}{ Yanlış Cevap Verenler } & \multirow[b]{2}{*}{$X^{2}$} & \multirow[b]{2}{*}{$\mathrm{P}$} \\
\hline & & $\begin{array}{l}\text { S1klık } \\
\text { (Kişi) }\end{array}$ & $\begin{array}{l}\text { Yüzde } \\
(\%)\end{array}$ & $\begin{array}{l}\text { Siklık } \\
\text { (Kişi) }\end{array}$ & $\begin{array}{l}\text { Yüzde } \\
\text { (\%) }\end{array}$ & & \\
\hline \multirow{2}{*}{ Cinsiyet } & Kadın & 89 & $61,0 \%$ & 57 & $39,0 \%$ & \multirow{2}{*}{1,634} & \multirow{2}{*}{0,201} \\
\hline & Erkek & 118 & $67,8 \%$ & 56 & $32,2 \%$ & & \\
\hline & & & & & & & \\
\hline \multirow{4}{*}{ Sinif } & Birinci sinıf & 41 & $48,8 \%$ & 43 & $51,2 \%$ & \multirow{4}{*}{14,089} & \multirow{4}{*}{0,003} \\
\hline & İkinci Sınıf & 56 & $72,7 \%$ & 21 & $27,3 \%$ & & \\
\hline & Üçüncü Sınıf & 52 & $65,0 \%$ & 28 & $35,0 \%$ & & \\
\hline & Dördüncü Sınıf & 58 & $73,4 \%$ & 21 & $26,6 \%$ & & \\
\hline \multirow{2}{*}{ Eğitim Şekli } & Birinci öğretim & 101 & $66,9 \%$ & 50 & $33,1 \%$ & \multirow{2}{*}{0,606} & \multirow{2}{*}{0,436} \\
\hline & İkinci öğretim & 106 & $62,7 \%$ & 63 & $37,3 \%$ & & \\
\hline \multirow{4}{*}{$\begin{array}{l}\text { Genel Not } \\
\text { Ortalamas1 }\end{array}$} & 2.00 veya alt1 & 47 & $61.0 \%$ & 30 & $39.0 \%$ & \multirow{4}{*}{8,978} & \multirow{4}{*}{0,030} \\
\hline & $2.01-2.75$ & 90 & $59,6 \%$ & 61 & $40,4 \%$ & & \\
\hline & $2.76-3.25$ & 55 & $79,7 \%$ & 14 & $20,3 \%$ & & \\
\hline & $3.26-4.00$ & 15 & $65,2 \%$ & 8 & $34,8 \%$ & & \\
\hline & & & & & & & \\
\hline \multirow{5}{*}{$\begin{array}{l}\text { Anne Eğitim } \\
\text { Durumu }\end{array}$} & $\begin{array}{l}\text { okuma yazma } \\
\text { bilmiyor }\end{array}$ & 7 & $43,8 \%$ & 9 & $56,3 \%$ & \multirow{5}{*}{9,449} & \multirow{5}{*}{0,051} \\
\hline & ilkokul & 84 & $60,9 \%$ & 54 & $39,1 \%$ & & \\
\hline & ortaokul & 36 & $61,0 \%$ & 23 & $39,0 \%$ & & \\
\hline & lise & 60 & $73,2 \%$ & 22 & $26,8 \%$ & & \\
\hline & $\begin{array}{l}\text { üniversite ve } \\
\text { Lisansüstü }\end{array}$ & 20 & $80,0 \%$ & 5 & $20,0 \%$ & & \\
\hline & & & & & & & \\
\hline \multirow{5}{*}{$\begin{array}{l}\text { Baba Eğitim } \\
\text { Durumu }\end{array}$} & $\begin{array}{l}\text { okuma yazma } \\
\text { bilmiyor }\end{array}$ & 0 & $0,0 \%$ & 2 & $100,0 \%$ & \multirow{5}{*}{11,559} & \multirow{5}{*}{0,021} \\
\hline & ilkokul & 52 & $59,1 \%$ & 36 & $40,9 \%$ & & \\
\hline & ortaokul & 53 & $58,9 \%$ & 37 & $41,1 \%$ & & \\
\hline & lise & 64 & $69,6 \%$ & 28 & $30,4 \%$ & & \\
\hline & $\begin{array}{l}\text { üniversite ve } \\
\text { Lisansüstü }\end{array}$ & 38 & $79,2 \%$ & 10 & $20,8 \%$ & & \\
\hline
\end{tabular}




\begin{tabular}{|c|c|c|c|c|c|c|c|}
\hline & & & & & & & \\
\hline \multirow{5}{*}{ Aylık Hane Geliri } & 1000 TL- Daha az & 20 & $60,6 \%$ & 13 & $39,4 \%$ & \multirow{5}{*}{5,695} & \multirow{5}{*}{0,223} \\
\hline & 1001 TL-2000 TL & 75 & $63,6 \%$ & 43 & $36,4 \%$ & & \\
\hline & 2001 TL-3000TL & 59 & $72,8 \%$ & 22 & $27,2 \%$ & & \\
\hline & 3001 TL-4000 TL & 28 & $53,8 \%$ & 24 & $46,2 \%$ & & \\
\hline & 4000 TL-Daha çok & 25 & $69,4 \%$ & 11 & $30,6 \%$ & & \\
\hline & $18-20$ & 57 & $57,6 \%$ & 42 & $42,4 \%$ & & \\
\hline Yaş & $21-22$ & 74 & $62,2 \%$ & 45 & $37,8 \%$ & 6,826 & 0,033 \\
\hline & 23 ve üzeri & 76 & $74,5 \%$ & 26 & $25,5 \%$ & & \\
\hline
\end{tabular}

Öğrencilerin temel yatırım bilgisinin ölçüldüğü bu sorunun sonuçlarının gösterildiği Tablo 4'de sınıf, genel not ortalaması, baba eğitim durumu ve yaş değişkenlerinin öğrencilerin finansal okuryazarlıkları üzerinde etkili olduğu görülmektedir. Genel olarak değerlendirildiğinde ise öğrencilerin \%64,7'sinin soruya doğru cevap verdiği görülmüştür. Yani öğrencilerin temel yatırım konusunda bilgi sahibi oldukları söylenebilir.

Soru 4.Bir şirketin hisse senedini satın almak yatırım fonlarına yatırım yapmaktan daha güvenlidir.

Tablo 5. Borsa Yatırım Araçları Bilgisi

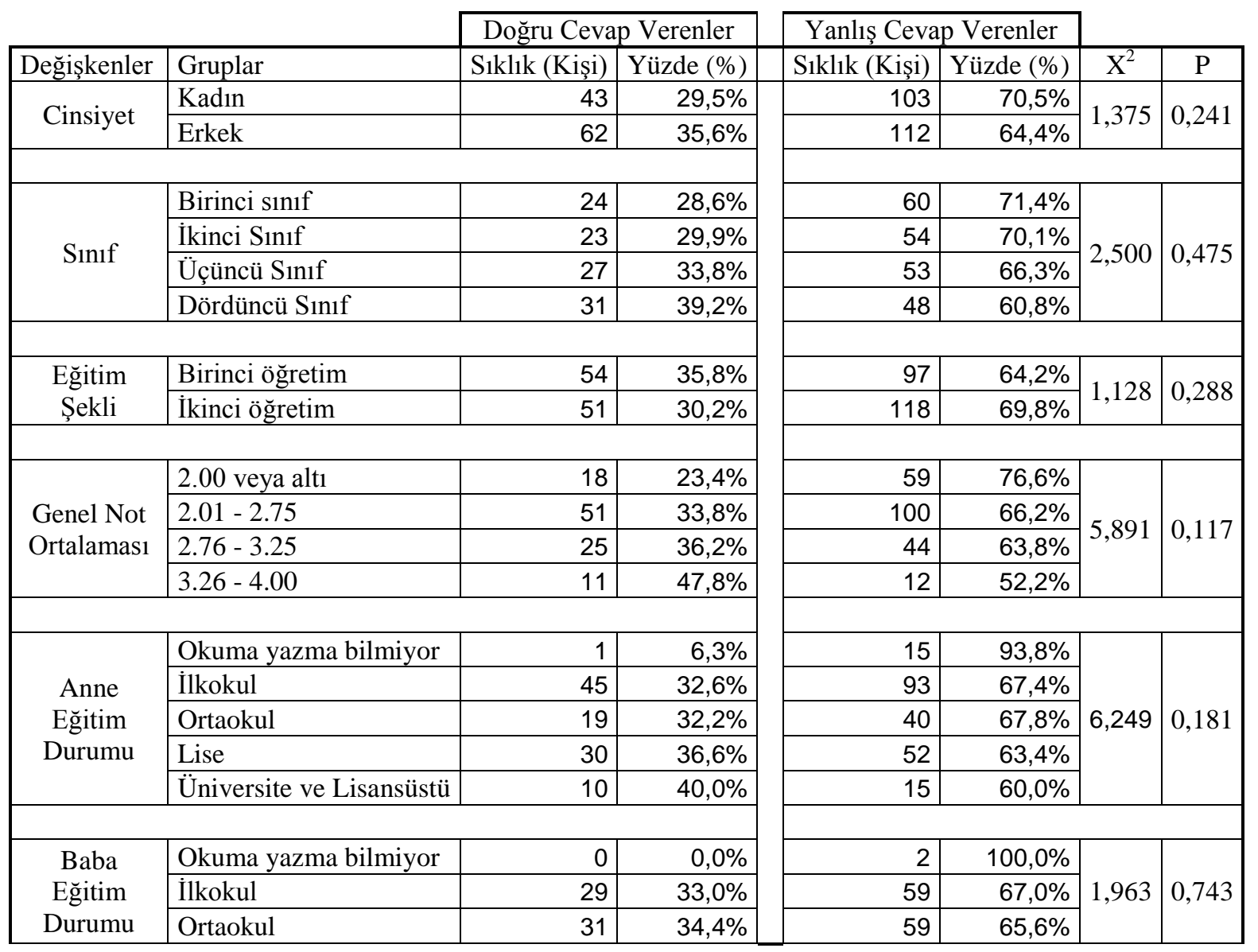




\begin{tabular}{|c|c|c|c|c|c|c|c|}
\hline & Lise & 32 & $34,8 \%$ & 60 & $65,2 \%$ & & \\
\hline & Üniversite ve Lisansüstü & 13 & $27,1 \%$ & 35 & $72,9 \%$ & & \\
\hline \multirow{5}{*}{$\begin{array}{l}\text { Aylık Hane } \\
\text { Geliri }\end{array}$} & 1000 TL- Daha az & 6 & $18,2 \%$ & 27 & $81,8 \%$ & \multirow{5}{*}{5,361} & \multirow{5}{*}{0,252} \\
\hline & 1001 TL-2000 TL & 37 & $31,4 \%$ & 81 & $68,6 \%$ & & \\
\hline & 2001 TL-3000TL & 27 & $33,3 \%$ & 54 & $66,7 \%$ & & \\
\hline & 3001 TL-4000 TL & 20 & $38,5 \%$ & 32 & $61,5 \%$ & & \\
\hline & 4000 TL-Daha çok & 15 & $41,7 \%$ & 21 & $58,3 \%$ & & \\
\hline \multirow{3}{*}{ Yaş } & $18-20$ & 27 & $27,3 \%$ & 72 & $72,7 \%$ & \multirow{3}{*}{3,317} & \multirow{3}{*}{0,190} \\
\hline & $21-22$ & 38 & $31,9 \%$ & 81 & $68,1 \%$ & & \\
\hline & 23 ve üzeri & 40 & $39,2 \%$ & 62 & $60,8 \%$ & & \\
\hline
\end{tabular}

Tablo 5'de öğrencilerin borsa yatırım araçlarıyla ilgili bilgileri ile demografik özellikleri arasında istatistiksel açıdan anlamlı bir ilişkinin olmadığ 1 tespit edilmiştir. Ayrıca soruya yanlış cevap veren öğrencilerin sayısının (\%67) daha fazla olduğu gözlenmiştir.

Soru 5.Hisse senetleri tahvillerden daha risklidir.

Tablo 6. Hisse Senedi-Tahvil Bilgisi

\begin{tabular}{|c|c|c|c|c|c|c|c|}
\hline \multirow[b]{2}{*}{ Değişkenler } & \multirow[b]{2}{*}{ Gruplar } & \multicolumn{2}{|c|}{$\begin{array}{c}\text { Doğru Cevap } \\
\text { Verenler }\end{array}$} & \multicolumn{2}{|c|}{$\begin{array}{c}\text { Yanlış Cevap } \\
\text { Verenler }\end{array}$} & \multirow[b]{2}{*}{$X^{2}$} & \multirow[b]{2}{*}{$\mathrm{P}$} \\
\hline & & $\begin{array}{l}\text { Siklık } \\
\text { (Kişi) }\end{array}$ & $\begin{array}{l}\text { Yüzde } \\
\text { (\%) }\end{array}$ & $\begin{array}{l}\text { S1klık } \\
\text { (Kiși) }\end{array}$ & $\begin{array}{l}\text { Yüzde } \\
\text { (\%) }\end{array}$ & & \\
\hline \multirow{2}{*}{ Cinsiyet } & Kadın & 47 & $32,2 \%$ & 99 & $67,8 \%$ & \multirow{2}{*}{6,303} & \multirow{2}{*}{0,012} \\
\hline & Erkek & 80 & $46,0 \%$ & 94 & $54,0 \%$ & & \\
\hline & & & & & & & \\
\hline \multirow{4}{*}{ Sinif } & Birinci sınıf & 19 & $22,6 \%$ & 65 & $77,4 \%$ & \multirow{4}{*}{23,341} & \multirow{4}{*}{0,000} \\
\hline & İkinci Sınıf & 31 & $40,3 \%$ & 46 & $59,7 \%$ & & \\
\hline & Üçüncü Sınıf & 30 & $37,5 \%$ & 50 & $62,5 \%$ & & \\
\hline & Dördüncü Sınıf & 47 & $59,5 \%$ & 32 & $40,5 \%$ & & \\
\hline \multirow{2}{*}{$\begin{array}{l}\text { Eğitim } \\
\text { Şekli }\end{array}$} & Birinci öğretim & 62 & $41,1 \%$ & 89 & $58,9 \%$ & \multirow{2}{*}{0,225} & \multirow{2}{*}{0,635} \\
\hline & İkinci öğretim & 65 & $38,5 \%$ & 104 & $61,5 \%$ & & \\
\hline \multirow{4}{*}{$\begin{array}{l}\text { Genel Not } \\
\text { Ortalamas1 }\end{array}$} & 2.00 veya alt 1 & 21 & $27,3 \%$ & 56 & $72,7 \%$ & \multirow{4}{*}{11,202} & \multirow{4}{*}{0,011} \\
\hline & $2.01-2.75$ & 59 & $39,1 \%$ & 92 & $60,9 \%$ & & \\
\hline & $2.76-3.25$ & 33 & $47,8 \%$ & 36 & $52,2 \%$ & & \\
\hline & $3.26-4.00$ & 14 & $60,9 \%$ & 9 & $39,1 \%$ & & \\
\hline & & & & & & & \\
\hline \multirow{5}{*}{$\begin{array}{l}\text { Anne } \\
\text { Eğitim } \\
\text { Durumu }\end{array}$} & Okuma yazma bilmiyor & 3 & $18,8 \%$ & 13 & $81,3 \%$ & \multirow{5}{*}{3,428} & \multirow{5}{*}{0,489} \\
\hline & İlkokul & 54 & $39,1 \%$ & 84 & $60,9 \%$ & & \\
\hline & Ortaokul & 25 & $42,4 \%$ & 34 & $57,6 \%$ & & \\
\hline & Lise & 34 & $41,5 \%$ & 48 & $58,5 \%$ & & \\
\hline & Üniversite ve Lisansüstü & 11 & $44,0 \%$ & 14 & $56,0 \%$ & & \\
\hline \multirow{4}{*}{$\begin{array}{c}\text { Baba } \\
\text { Eğitim } \\
\text { Durumu }\end{array}$} & Okuma yazma bilmiyor & 1 & $50,0 \%$ & 1 & $50,0 \%$ & \multirow{4}{*}{5,448} & \multirow{4}{*}{0,244} \\
\hline & İlkokul & 38 & $43,2 \%$ & 50 & $56,8 \%$ & & \\
\hline & Ortaokul & 28 & $31,1 \%$ & 62 & $68,9 \%$ & & \\
\hline & Lise & 36 & $39,1 \%$ & 56 & $60,9 \%$ & & \\
\hline
\end{tabular}




\begin{tabular}{|c|c|c|c|c|c|c|c|}
\hline & Üniversite ve Lisansüstü & 24 & $50,0 \%$ & 24 & $50,0 \%$ & & \\
\hline \multirow{5}{*}{$\begin{array}{l}\text { Aylik Hane } \\
\text { Geliri }\end{array}$} & 1000 TL- Daha az & 11 & $33,3 \%$ & 22 & $66,7 \%$ & \multirow{5}{*}{4,790} & \multirow{5}{*}{0,310} \\
\hline & 1001 TL-2000 TL & 46 & $39,0 \%$ & 72 & $61,0 \%$ & & \\
\hline & 2001 TL-3000TL & 39 & $48,1 \%$ & 42 & $51,9 \%$ & & \\
\hline & 3001 TL-4000 TL & 16 & $30,8 \%$ & 36 & $69,2 \%$ & & \\
\hline & 4000 TL-Daha çok & 15 & $41,7 \%$ & 21 & $58,3 \%$ & & \\
\hline \multirow{3}{*}{ Yaş } & $18-20$ & 30 & $30,3 \%$ & 69 & $69,7 \%$ & \multirow{3}{*}{7,355} & \multirow{3}{*}{0,025} \\
\hline & $21-22$ & 47 & $39,5 \%$ & 72 & $60,5 \%$ & & \\
\hline & 23 ve üzeri & 50 & $49,0 \%$ & 52 & $51,0 \%$ & & \\
\hline
\end{tabular}

Borsa yatırım araçlarından olan hisse senedi ve tahvil ile ilgili bilgilerinin değerlendirildiği bu soruda cinsiyet, sınıf, genel not ortalaması ve yaş değişkenleri ile finansal okuryazarlık düzeyleri arasında anlamlı bir ilişki olduğu belirlenmiştir. Erkek öğrencilerin soruyu cevaplamada kız öğrencilere göre daha başarılı olduğu, öğrencilerin bir üst sınıfa geçtikte başarı oranlarının arttı̆̆ı ve aldıkları eğitimin borsa yatırım araçlarıyla ilgili bilgileri kazanmalarında etkili olduğu, genel not ortalamasının artmasıyla soruya daha fazla doğru cevap verildiği ve yaşları ilerledikçe bilgi düzeylerinin arttığı söylenebilir. Genel olarak değerlendirildiğinde öğrencilerin \%60’1 soruya yanlış cevap vermiştir.

Soru 6.Hisse Senedi Piyasasının (Borsa) temel işlevini en doğru şekilde tanımlayan seçeneği lütfen işaretleyiniz.

A-Hisse senedi getirilerinin tahmin edilmesine yarar.

B-Hisse senedi fiyatlarının artmasına sebep olur.

C-Hisse senedi almak ve satmak isteyenleri bir araya getirir.

D-Bilmiyorum.

Tablo 7. Borsanın Temel Fonksiyonu Bilgisi

\begin{tabular}{|c|c|c|c|c|c|c|c|}
\hline & & \multicolumn{2}{|c|}{$\begin{array}{c}\text { Doğru Cevap } \\
\text { Verenler }\end{array}$} & \multicolumn{2}{|c|}{$\begin{array}{c}\text { Yanlış Cevap } \\
\text { Verenler }\end{array}$} & \multirow[b]{2}{*}{$X^{2}$} & \multirow[b]{2}{*}{$\mathrm{P}$} \\
\hline Değişkenler & Gruplar & $\begin{array}{l}\text { Siklik } \\
\text { (Kişi) }\end{array}$ & \begin{tabular}{|l}
$\begin{array}{l}\text { Yüzde } \\
(\%)\end{array}$ \\
\end{tabular} & $\begin{array}{l}\text { Siklık } \\
\text { (Kişi) }\end{array}$ & \begin{tabular}{|l|}
$\begin{array}{l}\text { Yüzde } \\
(\%)\end{array}$ \\
\end{tabular} & & \\
\hline \multirow{2}{*}{ Cinsiyet } & Kadın & 73 & $50,0 \%$ & 73 & $50,0 \%$ & \multirow{2}{*}{0,042} & \multirow{2}{*}{0,838} \\
\hline & Erkek & 85 & $48,9 \%$ & 89 & $51,1 \%$ & & \\
\hline \multirow{4}{*}{ Sinıf } & Birinci sınıf & 26 & $31,0 \%$ & 58 & $69,0 \%$ & \multirow{4}{*}{17,373} & \multirow{4}{*}{0,001} \\
\hline & İkinci Sınıf & 44 & $57,1 \%$ & 33 & $42,9 \%$ & & \\
\hline & Üçüncü Sınıf & 40 & $50,0 \%$ & 40 & $50,0 \%$ & & \\
\hline & Dördüncü Sınıf & 48 & $60,8 \%$ & 31 & $39,2 \%$ & & \\
\hline \multirow{2}{*}{ Eğitim Şekli } & Birinci öğretim & 79 & $52,3 \%$ & 72 & $47,7 \%$ & \multirow{2}{*}{0,991} & \multirow{2}{*}{0,320} \\
\hline & İkinci öğretim & 79 & $46,7 \%$ & 90 & $53,3 \%$ & & \\
\hline Genel Not Ortalaması & 2.00 veya altı & 36 & $46,8 \%$ & 41 & $53,2 \%$ & 2,261 & 0,520 \\
\hline
\end{tabular}




\begin{tabular}{|c|c|c|c|c|c|c|c|}
\hline & $2.01-2.75$ & 71 & $47,0 \%$ & 80 & $53,0 \%$ & & \\
\hline & $2.76-3.25$ & 37 & $53,6 \%$ & 32 & $46,4 \%$ & & \\
\hline & $3.26-4.00$ & 14 & $60,9 \%$ & 9 & $39,1 \%$ & & \\
\hline \multirow{5}{*}{ Anne Eğitim Durumu } & $\begin{array}{l}\text { Okuma yazma } \\
\text { bilmiyor }\end{array}$ & 7 & $43,8 \%$ & 9 & $56,3 \%$ & \multirow{5}{*}{6,928} & \multirow{5}{*}{0,140} \\
\hline & İlkokul & 76 & $55,1 \%$ & 62 & $44,9 \%$ & & \\
\hline & \begin{tabular}{|l|} 
Ortaokul \\
\end{tabular} & 21 & $35,6 \%$ & 38 & $64,4 \%$ & & \\
\hline & \begin{tabular}{|l|} 
Lise \\
\end{tabular} & 40 & $48,8 \%$ & 42 & $51,2 \%$ & & \\
\hline & $\begin{array}{l}\text { Üniversite ve } \\
\text { Lisansüstü }\end{array}$ & 14 & $56,0 \%$ & 11 & $44,0 \%$ & & \\
\hline & & & & & & & \\
\hline \multirow{5}{*}{ Baba Eğitim Durumu } & $\begin{array}{l}\text { Okuma yazma } \\
\text { bilmiyor }\end{array}$ & 2 & $100,0 \%$ & 0 & $0,0 \%$ & \multirow{5}{*}{2,705} & \multirow{5}{*}{0,608} \\
\hline & İlkokul & 44 & $50,0 \%$ & 44 & $50,0 \%$ & & \\
\hline & Ortaokul & 41 & $45,6 \%$ & 49 & $54,4 \%$ & & \\
\hline & Lise & 47 & $51,1 \%$ & 45 & $48,9 \%$ & & \\
\hline & $\begin{array}{l}\text { Üniversite ve } \\
\text { Lisansüstü }\end{array}$ & 24 & $50,0 \%$ & 24 & $50,0 \%$ & & \\
\hline \multirow{6}{*}{ Aylık Hane Geliri } & & & & & & \multirow{6}{*}{3,006} & \\
\hline & 1000 TL- Daha az & 17 & $51,5 \%$ & 16 & $48,5 \%$ & & \multirow{5}{*}{0,557} \\
\hline & 1001 TL-2000 TL & 60 & $50,8 \%$ & 58 & $49,2 \%$ & & \\
\hline & 2001 TL-3000TL & 42 & $51,9 \%$ & 39 & $48,1 \%$ & & \\
\hline & 3001 TL-4000 TL & 20 & $38,5 \%$ & 32 & $38,5 \%$ & & \\
\hline & 4000 TL-Daha çok & 19 & $52,8 \%$ & 17 & $47,2 \%$ & & \\
\hline \multirow{3}{*}{ Yaş } & $18-20$ & 38 & $38,4 \%$ & 61 & $61,6 \%$ & \multirow{3}{*}{8,480} & \multirow{3}{*}{0,014} \\
\hline & $21-22$ & 60 & $50,4 \%$ & 59 & $49,6 \%$ & & \\
\hline & 23 ve üzeri & 60 & $58,8 \%$ & 42 & $41,2 \%$ & & \\
\hline
\end{tabular}

Tablo 7'de öğrencilerin borsanın temel işlevi hakkındaki bilgilerinin değerlendirildiği demografik değişskenlerden sınıf ve yaş değişkenleri ile finansal okuryazarlık bilgi düzeyleri arasında istatistiksel açıdan anlamlı bir ilişki belirlenmiştir. Okudukları sınıf bazında değerlendirildiğinde bölüme yeni başlayan öğrencilerin bölümde okuyan diğer öğrencilere göre soruyu doğru cevaplamada daha az başarılı oldukları görülmektedir. Bu durumda finans ile ilgili olarak aldıkları eğitimin borsa ile ilgili bilgilerini geliştirmede etkili olduğunu söylemek mümkündür. Yaş değişkeni de sınıf değişkeni ile paralellik göstermektedir.

Soru 7. Aşağıdaki ifadelerden hangisi doğrudur?

A-Yatırım fonlarına yatırım yapıldığında, ilk yıl içinde yatırılan para çekilemez.

B-Yatırım fonları birçok varlığa yatırım yapabilir. Örneğin hem hisse senedine hem de tahvile yatırım yapılabilir.

C-Yatırım fonları, geçmiş performanslarına bağlı olarak belirli bir getiri oranını garanti ederler.

D- Yukarıdaki seçeneklerin hiçbiri 
E-Bilmiyorum.

Tablo 8. Yatırım Fonları ile İlgili Bilgileri

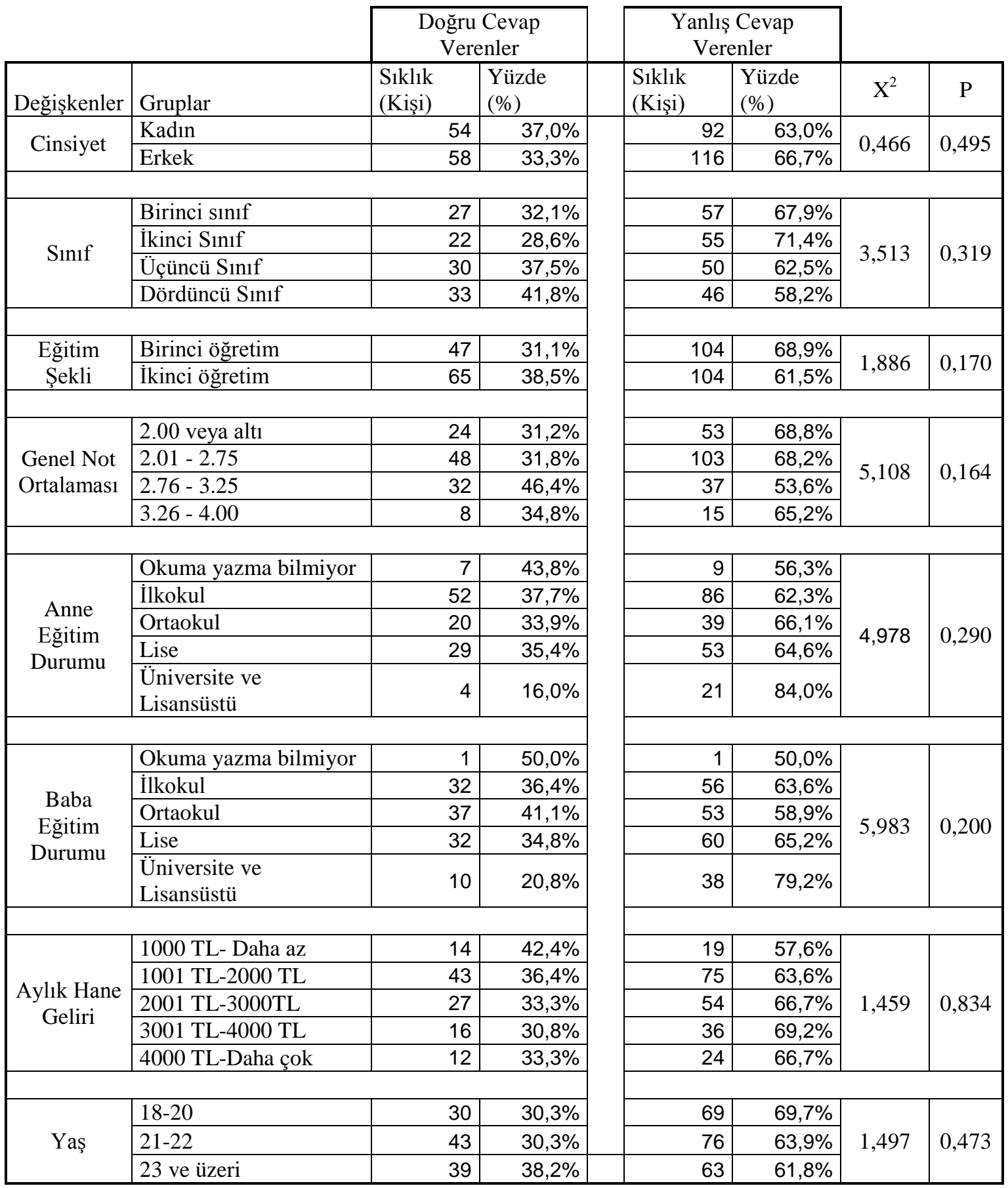

Yatırım fonları hakkındaki bilgilerinin değerlendirildiği Tablo 8'de demografik değişkenler ile finansal okur yazarlık düzeyleri arasında anlamlı bir ilişki belirlenememiştir. Genel olarak değerlendirildiğinde ise öğrencilerin \%35 inin soruyu doğru cevapladığ 
görülmektedir ve bu durumda öğrencilerin yatırım fonları hakkında bilgilerinin yeterli olmadığı söylenebilir.

Soru 8. Faiz oranları düşerse, tahvil fiyatları sizce hangi yönde değişir?
A-Yükselir
B-Düşer
C-Aynı kalır
D-Önceki seçeneklerin hiçbiri
E-Bilmiyorum

Tablo 9. Faiz Oranı- Tahvil İlişkisi Bilgisi

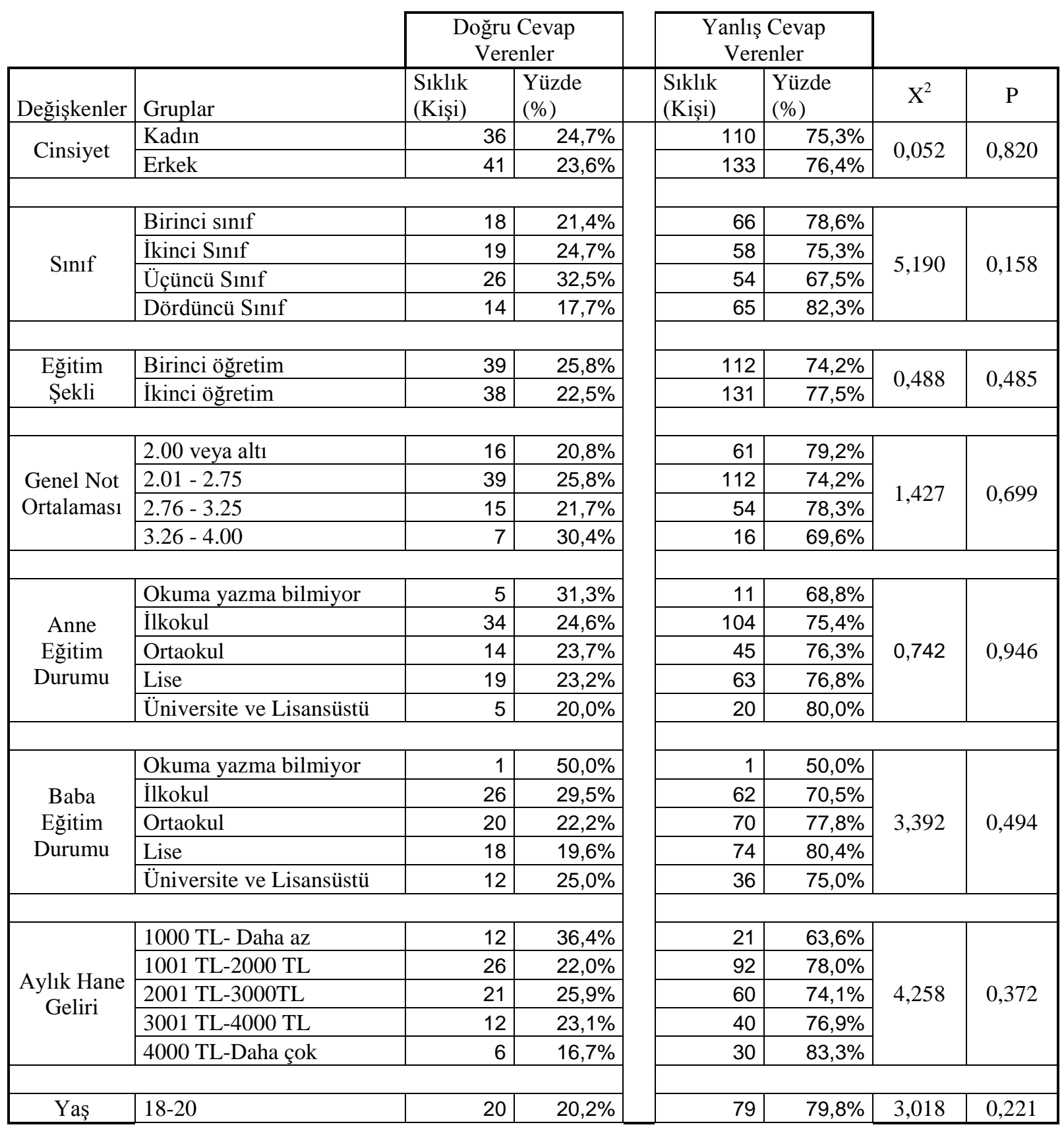




\begin{tabular}{|l|r|r|r|r|r|} 
& $21-22$ & 35 & $29,4 \%$ & 84 & $70,6 \%$ \\
\cline { 1 - 2 } & 22 & $21,6 \%$ & 80 & $78,4 \%$ & \\
\hline
\end{tabular}

Tablo 9'a göre öğrencilerin faiz oranı-tahvil fiyatı ilişkisi bilgileri ile demografik değişkenler arasında anlamlı bir ilişki görülmemektedir. Genel olarak bakıldığında ögrencilerin \%76 sının soruya yanlış cevap verdiği görülmektedir.

Soru 9-Uzun vade düşünüldüğünde (15-20 yıl gibi) sizce hangi varlık daha yüksek getiri sağlar?
A-Tasarruf hesab1
B-Tahvil
C-Hisse senedi
D-Bilmiyorum

Tablo 10.Uzun Vade Getiri Bilgisi

\begin{tabular}{|c|c|c|c|c|c|c|c|}
\hline \multirow{2}{*}{$\begin{array}{l}\text { Değişkenl } \\
\text { er }\end{array}$} & \multirow[b]{2}{*}{ Gruplar } & \multicolumn{2}{|c|}{$\begin{array}{c}\text { Doğru Cevap } \\
\text { Verenler }\end{array}$} & \multicolumn{2}{|c|}{$\begin{array}{c}\text { Yanlış Cevap } \\
\text { Verenler }\end{array}$} & \multirow[b]{2}{*}{$X^{2}$} & \multirow[b]{2}{*}{$\mathrm{P}$} \\
\hline & & $\begin{array}{l}\text { Siklik } \\
\text { (Kişi) }\end{array}$ & $\begin{array}{l}\text { Yüzde } \\
\text { (\%) }\end{array}$ & $\begin{array}{l}\text { Siklık } \\
\text { (Kişi) }\end{array}$ & $\begin{array}{l}\text { Yüzde } \\
(\%)\end{array}$ & & \\
\hline \multirow{2}{*}{ Cinsiyet } & Kadın & 60 & $41,1 \%$ & 86 & $58,9 \%$ & \multirow{2}{*}{1,756} & \multirow{2}{*}{0,185} \\
\hline & Erkek & 59 & $33,9 \%$ & 115 & $66,1 \%$ & & \\
\hline & & & & & & & \\
\hline \multirow{4}{*}{ Sinif } & Birinci sınıf & 32 & $38,1 \%$ & 52 & $61,9 \%$ & \multirow{4}{*}{1,294} & \multirow{4}{*}{0,731} \\
\hline & İkinci Sınıf & 27 & $35,1 \%$ & 50 & $64,9 \%$ & & \\
\hline & Üçüncü Sınıf & 27 & $33,8 \%$ & 53 & $66,3 \%$ & & \\
\hline & Dördüncü Sınıf & 33 & $41,8 \%$ & 46 & $58,2 \%$ & & \\
\hline \multirow{2}{*}{$\begin{array}{l}\text { Eğitim } \\
\text { Şekli }\end{array}$} & Birinci öğretim & 57 & $37,7 \%$ & 94 & $62,3 \%$ & \multirow{2}{*}{0,039} & \multirow{2}{*}{0,844} \\
\hline & İkinci öğretim & 62 & $36,7 \%$ & 107 & $63,3 \%$ & & \\
\hline & & & & & & & \\
\hline \multirow{4}{*}{$\begin{array}{c}\text { Genel Not } \\
\text { Ortalamas } \\
1\end{array}$} & 2.00 veya altı & 31 & $40,3 \%$ & 46 & $59,7 \%$ & \multirow{4}{*}{2,775} & \multirow{4}{*}{0,428} \\
\hline & $2.01-2.75$ & 160 & $39,7 \%$ & 91 & $60,3 \%$ & & \\
\hline & $2.76-3.25$ & 20 & $29,0 \%$ & 49 & $71,0 \%$ & & \\
\hline & $3.26-4.00$ & 8 & $34,8 \%$ & 15 & $65,2 \%$ & & \\
\hline & & & & & & & \\
\hline \multirow{5}{*}{$\begin{array}{c}\text { Anne } \\
\text { Eğitim } \\
\text { Durumu }\end{array}$} & Okuma yazma bilmiyor & 6 & $37,5 \%$ & 10 & $62,5 \%$ & \multirow{5}{*}{1,81} & \multirow{5}{*}{0,771} \\
\hline & İlkokul & 49 & $35,5 \%$ & 89 & $64,5 \%$ & & \\
\hline & Ortaokul & 20 & $33,9 \%$ & 39 & $66,1 \%$ & & \\
\hline & Lise & 32 & $39,0 \%$ & 50 & $61,0 \%$ & & \\
\hline & Üniversite ve Lisansüstü & 12 & $48,0 \%$ & 13 & $52,0 \%$ & & \\
\hline & & & & & & & \\
\hline \multirow{5}{*}{$\begin{array}{c}\text { Baba } \\
\text { Eğitim } \\
\text { Durumu }\end{array}$} & Okuma yazma bilmiyor & 1 & $50,0 \%$ & 1 & $50,0 \%$ & \multirow{5}{*}{0,811} & \multirow{5}{*}{0,937} \\
\hline & İlkokul & 30 & $34,1 \%$ & 58 & $65,9 \%$ & & \\
\hline & Ortaokul & 36 & $40,0 \%$ & 54 & $60,0 \%$ & & \\
\hline & Lise & 34 & $37,0 \%$ & 58 & $63,0 \%$ & & \\
\hline & Üniversite ve Lisansüstü & 18 & $37,5 \%$ & 30 & $62,5 \%$ & & \\
\hline & & & & & & & \\
\hline \multirow{4}{*}{$\begin{array}{l}\text { Aylik } \\
\text { Hane } \\
\text { Geliri }\end{array}$} & 1000 TL- Daha az & 16 & $48,5 \%$ & 17 & $51,5 \%$ & \multirow{4}{*}{3,497} & \multirow{4}{*}{0,478} \\
\hline & 1001 TL-2000 TL & 42 & $35,6 \%$ & 76 & $64,4 \%$ & & \\
\hline & 2001 TL-3000TL & 33 & $40,7 \%$ & 48 & $59,3 \%$ & & \\
\hline & 3001 TL-4000 TL & 17 & $32,7 \%$ & 35 & $67,3 \%$ & & \\
\hline
\end{tabular}




\begin{tabular}{|c|c|c|c|c|c|c|c|}
\hline & 4000 TL-Daha çok & 11 & $30,6 \%$ & 25 & $69,4 \%$ & & \\
\hline \multirow{3}{*}{ Yaş } & $18-20$ & 37 & $37,4 \%$ & 62 & $62,6 \%$ & \multirow{3}{*}{2,954} & \multirow{3}{*}{0,228} \\
\hline & $21-22$ & 38 & $31,9 \%$ & 81 & $68,1 \%$ & & \\
\hline & 23 ve üzeri & 44 & $43,1 \%$ & 58 & $56,9 \%$ & & \\
\hline
\end{tabular}

Tablo 10'da öğrencilerin uzun vadedeki getiri bilgisi ile demografik değişkenler arasında anlamlı bir ilişki olmadığı açıkça görülmektedir. Öğrencilerin \%63 ü soruya yanlış cevap vermiştir.

Soru 10. Yatırımcinın parasıyla farklı varlıklar alması, onun para kaybetme riskini hangi yönde etkiler?

Tablo 11. Varlık Çeşitlendirmesi Bilgisi

\begin{tabular}{|c|c|c|c|c|c|c|c|}
\hline & \multirow{2}{*}{\multicolumn{2}{|c|}{$\begin{array}{c}\text { Doğru Cevap } \\
\text { Verenler }\end{array}$}} & \multirow{2}{*}{\multicolumn{2}{|c|}{$\begin{array}{c}\text { Yanlış Cevap } \\
\text { Verenler }\end{array}$}} & \\
\hline & & & & & & & \\
\hline Değişkenler & Gruplar & $\begin{array}{l}\text { Siklık } \\
\text { (Kişi) }\end{array}$ & $\begin{array}{l}\text { Yüzde } \\
(\%)\end{array}$ & \begin{tabular}{|l|} 
Siklık \\
(Kişi)
\end{tabular} & \begin{tabular}{|l} 
Yüzde \\
$(\%)$
\end{tabular} & $X^{2}$ & $\mathrm{P}$ \\
\hline \multirow{2}{*}{ Cinsiyet } & Kadın & 53 & $36,3 \%$ & 93 & $63,7 \%$ & \multirow{2}{*}{3,060} & \multirow{2}{*}{0,080} \\
\hline & Erkek & 80 & $46,0 \%$ & 94 & $54,0 \%$ & & \\
\hline & & & & & & & \\
\hline \multirow{4}{*}{ Sinif } & Birinci sinif & 26 & $31,0 \%$ & 58 & $69,0 \%$ & \multirow{4}{*}{9,128} & \multirow{4}{*}{0,028} \\
\hline & İkinci Sınıf & 28 & $36,4 \%$ & 49 & $63,6 \%$ & & \\
\hline & Üçüncü Sınıf & 39 & $48,8 \%$ & 41 & $51,3 \%$ & & \\
\hline & Dördüncü Sınıf & 40 & $50,6 \%$ & 39 & $49,4 \%$ & & \\
\hline & & & & & & & \\
\hline \multirow{2}{*}{$\begin{array}{c}\text { Eğitim } \\
\text { Şekli }\end{array}$} & Birinci öğretim & 64 & $42,4 \%$ & 87 & $57,6 \%$ & \multirow{2}{*}{0,079} & \multirow{2}{*}{0,778} \\
\hline & İkinci öğretim & 69 & $40,8 \%$ & 100 & $59,2 \%$ & & \\
\hline & & & & & & & \\
\hline \multirow{4}{*}{$\begin{array}{l}\text { Genel Not } \\
\text { Ortalaması }\end{array}$} & 2.00 veya alt1 & 23 & $29,9 \%$ & 54 & $70,1 \%$ & \multirow{4}{*}{7,249} & \multirow{4}{*}{0,064} \\
\hline & $2.01-2.75$ & 65 & $43,0 \%$ & 86 & $57,0 \%$ & & \\
\hline & $2.76-3.25$ & 32 & $46,4 \%$ & 37 & $53,6 \%$ & & \\
\hline & $3.26-4.00$ & 13 & $56,5 \%$ & 10 & $43,5 \%$ & & \\
\hline \multirow{5}{*}{$\begin{array}{l}\text { Anne } \\
\text { Eğitim } \\
\text { Durumu }\end{array}$} & Okuma yazma bilmiyor & 7 & $43,8 \%$ & 9 & $56,3 \%$ & \multirow{5}{*}{1,699} & \multirow{5}{*}{0,791} \\
\hline & İlkokul & 59 & $42,8 \%$ & 79 & $57,2 \%$ & & \\
\hline & Ortaokul & 27 & $45,8 \%$ & 32 & $54,2 \%$ & & \\
\hline & Lise & 32 & $39,0 \%$ & 50 & $61,0 \%$ & & \\
\hline & Üniversite ve Lisansüstü & 8 & $32,0 \%$ & 17 & $68,0 \%$ & & \\
\hline \multirow{5}{*}{$\begin{array}{c}\text { Baba } \\
\text { Eğitim } \\
\text { Durumu }\end{array}$} & Okuma yazma bilmiyor & 2 & $100,0 \%$ & 0 & $0,0 \%$ & \multirow{5}{*}{7,918} & \multirow{5}{*}{0,095} \\
\hline & İlkokul & 33 & $37,5 \%$ & 55 & $62,5 \%$ & & \\
\hline & Ortaokul & 46 & $51,1 \%$ & 44 & $48,9 \%$ & & \\
\hline & Lise & 34 & $37,0 \%$ & 58 & $63,0 \%$ & & \\
\hline & Üniversite ve Lisansüstü & 18 & $37,5 \%$ & 30 & $62,5 \%$ & & \\
\hline \multirow{2}{*}{$\begin{array}{c}\text { Aylık Hane } \\
\text { Geliri }\end{array}$} & 1000 TL- Daha az & 12 & $36,4 \%$ & 21 & $63,6 \%$ & \multirow{2}{*}{5,906} & \multirow{2}{*}{0,206} \\
\hline & 1001 TL-2000 TL & 57 & $48,3 \%$ & 61 & $51,7 \%$ & & \\
\hline
\end{tabular}




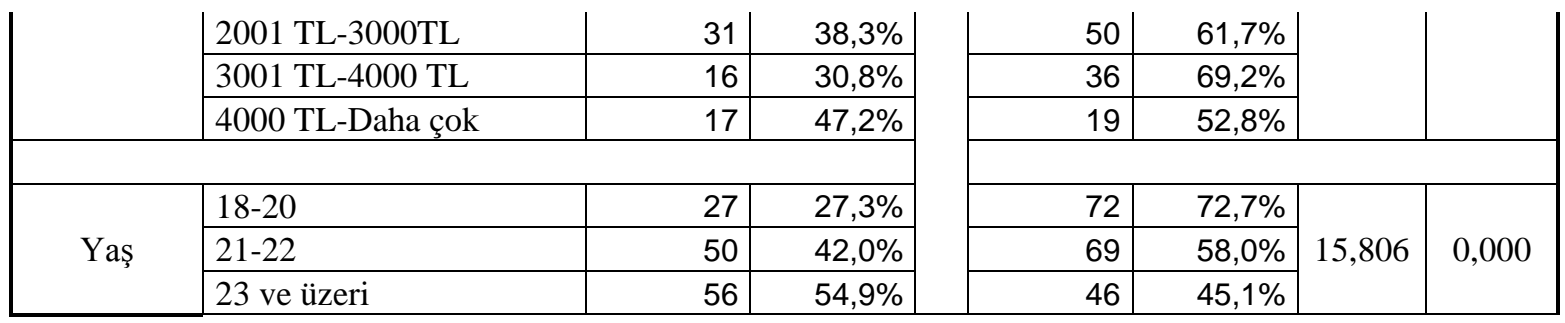

Varlık çeşitlendirmesi ile ilgili bilgilerinin ölçüldüğü bu sorunun sonuçları ise Tablo 11 'de verilmiştir. Sınıf ve yaş değişkenleri arasında istatistikî olarak anlamlı ilişki olduğu belirlenmiştir. Okudukları sınıf bazında değerlendirildiğinde aldıkları eğitimin finansal okuryazarlık konusunda bilgilerini arttırmada etkili olduğu söylenebilir.

\section{SONUÇ}

Finansal bilgi ve becerileri aileden başlayarak kazanmak ve eğitim hayatı boyunca öğrenmek önemli olmakla birlikte, finansal bilgi birikimine ulaşmak ve bunu devam ettirmek insanların yaşamları boyunca devam eden bir süreçtir. Bireylerin aldıkları finansal kararlar yaşam standartlarında önemli değişimlere neden olabilir. Bu nedenle hayatın her aşamasında finansal eğitimin önemi ayrı bir önem taşımaktadır. Bireyler aldıkları finansal eğitim yoluyla, finans konusunda gereken bilgi ve becerileri kazanarak gelecekteki finansal kararları ile ilgili daha iyi seçenekler belirleyebilir ve kendilerini finansal açıdan karşılaşabilecekleri risklere karşı rahatlıkla koruyabilirler. Kendi finansal durumlarını iyi yönetebilen bu bireyler ise ülke ekonomisinin güçlenmesine katkı sağlayacaktır.

Bulgular incelendiğinde öğrencilerin temel düzeyde faiz, enflasyon, yatırım bilgisi ve borsanın temel işlevi gibi sorulara çoğunluğun doğru cevap verdiği ve temel finans düzeyinde daha bilgili olduğu tespit edilmiştir. Diğer taraftan öğrencilerin büyük çoğunluğunun borsa yatırım araçları, hisse senedi- tahvil, yatırım fonları, uzun vade getirisi ve varlık çeşitlendirmesi hakkındaki sorulara yanlış cevap verdiği ve ileri düzeyde finans konusunda daha az bilgi sahibi oldukları belirlenmiştir. Bu nedenle, üniversite öğrencilerinin temel düzeyde finansal bilgiye sahip oldukları sonucuna ulaşılmıştır. Finansal bilgi düzeylerinin demografik değişkenler ile ilişkisi üzerine kurulan hipotez sonuçları ise;

- $\quad$ Temel düzeyde faiz bilgisi sınıf, eğitim şekli ve baba eğitim durumu değişkenlerinden bağımsız değildir.

- Temel düzeyde enflasyon bilgisi cinsiyet ve yaş değişkeninden bağımsız değildir.

- $\quad$ Temel düzeyde yatırım bilgisi genel not ortalaması, baba eğitim durumu ve yaş değişkelerinden bağımsız değildir.

- $\quad$ Hisse senedi- tahvil bilgisi cinsiyet, sınıf, genel not ortalaması ve yaş değişkelerinden bağımsız değildir

- Borsanın temel fonksiyonu bilgisi sınıf ve yaş değişkelerinden bağımsız değildir

- Varlık çeşitlendirmesi bilgisi sınıf ve yaş değişkelerinden bağımsız değildir 
şeklinde belirlenmiştir. Sınıf değişkeninin öğrencilerin finansal okuryazarlık düzeyleri üzerinde etkili olması öğrencilerin finans ile ilgili dersleri almalarının finansal okuryazarlıklarını olumlu yönde etkilediği söylenebilir. Eğitim şekline göre birinci öğretimde öğrenim gören öğrencilerin daha başarılı oldukları belirlenmiştir. Ayrıca genel not ortalaması yükseldikçe başarı düzeyinin artması beklenir ve çıkan sonuçlar da bunu doğrulamaktadır. Cinsiyet değişskeninin de finansal okuryazarlık konusunda etkili olduğu ve erkek öğrencilerin finansal konularda kızlardan daha başarılı olduğu görülmektedir. Baba eğitim durumunun etkili olması ise ailede paranın yönetiminin genel olarak baba da olması ve babanın finansal konudaki bilgisi ve paylaşımı öğrencilerin bilgisi üzerinde etkili olmuştur. Son olarak yaş değişkeni ele alındığında bireylerin yaşları ilerledikçe hayata bakış açılarının değişmesiyle birlikte, almış oldukları bireysel sorumluluklar artıkça paranın yönetimi konusunda daha bilinçli oldukları söylenebilir. Aylık hane geliri ve anne eğitim durumu değişkenleri ise hiçbir finansal bilgi türü ile ilişkili bulunamamıştır.

Sonuç olarak çalışmada öğrencilerin temel düzeyde finans bilgisine sahip olduğu ve ileri düzeyde finans konusunda daha az bilgiye sahip olduğu belirlenmiştir. İşletme bölümü öğrencilerinin almış oldukları eğitimin finansal bilgilerini artırdığı ancak öğrencilerin finansal bilgilerini geliştirmeleri gerektiği sonucuna ulaşılmıştır. Ayrıca finans eğitimi alan öğrencilerin finansal bilgilerini geliştirmeleri sonucuna ulaşılan çalışmada, insanların yaşam kalitesini yükseltmek için finansal okuma yazma programları oluşturularak, farklı fakültelerde okuyan öğrencilerin kişisel finansman yeteneklerini geliştirmesine destek olunabilir ve finans alanındaki dersler oluşturulacak olan finansal okuma yazma programları ile kampüste bulunan öğrencilere sunulabilir. Bu derslere katılım teşvik edilerek öğrencilerin pratik yapmaları ve finansal bilgi ve yönetim becerileri kazanmaları sağlanabilir.

\section{KAYNAKLAR}

Adeleke, Titus (2013),"The Effects of Gender and Gender Role on the Financial Literacy of College Students", Wilmington, North Carolina: Oklahoma State University, July, pp. 1-78.

Agarwal, Monika - Gupta,Meenu (2014), “Awareness of Financial Literacy Among College Students “,- Apeejay-Journal of Management Sciences and Technology, 2 (1), pp:113.

Albeerdy, Muhammad I - Gharleghi Behrooz (2015, "Determinants of the Financial Literacy among College Students in Malaysia”,International Journal of Business Administration, Vol 6, No 3, pp.15-24.

Chen, Haiyang - Ronald P. Volpe. (1998), “An Analysis Of Personal Financial Literacy Among College Students” Financial Services Review, 7(2), pp. 107-128.

Cihangir, Mehmet - Ergin, Erhan (2015), "Finansal Okuryazarlığın Temel Düzeyde İncelenmesi: Osmaniye İlinde Ankete Dayalı Bir Araştırma”, Akademik Sosyal Araştırmalar Dergisi, Y1l: 3, Sayı: 13, ss. 492-511. 
Çam, Alper Veli- Barut, Abdulkadir (2015), “ Finansal Okuryazarlık Düzeyi ve Davranışları: Gümüşhane Üniversitesi Önlisans Öğrencileri Üzerinde Bir Araştırma”, Küresel İktisat ve İşletme Çalışmaları Dergisi, Cilt 4, Sayı 7, ss. 63-72.

Er, Fikret- Temizel, Fatih- Özdemir, Ali - Sönmez, Harun (2014), “ Lisans Eğitim Programlarının Finansal Okuryazarlık Düzeyine Etkisinin Araştırılması: Türkiye Örneğì”, Anadolu Üniversitesi Sosyal Bilimler Dergisi, Vol: 14, Sayı:4, ss. 113-126.

Ergün, Bahadır- Şahin, Arzu- Ergin, Erhan (2014), “Finansal Okuryazarlık: İşletme Bölümü Öğrencileri Üzerine Bir Çalışma”, Uluslararası Sosyal Araştırmalar Dergisi, 7 (34), ss. 847-864.

Güngör, M. - Bulut, Y.(2008), “Ki-Kare Testi Üzerine”, Doğu Anadolu Bölgesi Araştırmaları, ss:84-89.

Jorgensen, Bryce L. - Jyoti Savla (2010), "Financial Literacy of Young Adults: The Importance of Parental Socialization”, Interdisciplinary Journal of Applied Family Studies, 59(4), pp. 465-478.

Kılıç, Yunus- Ata, H.Ali- Seyrek, İbrahim H. (2015), “ Finansal Okuryazarlık: Üniversite Öğrencilerine Yönelik Bir Araştırma”, Muhasebe ve Finansman Dergisi, Sayı: 66, ss. 129-150.

Lusardi, Annamaria (2008), “Financial Literacy: An Essential Tool for Informed Consumer Choice”, National Bureau Of Economic Research, pp. 1-29.

Mahdzan, Nurul Shahnaz- Tabiani, Saleh (2013), “The Impact of Financial Literacy on Individual Saving: An Exploratory Study in The Malaysian Context”,Transformation in Business \&Economics, Vol. 12, Issue 1, pp. 41-55.

Potrich, Ani Caroline Grigion-Vieira, Kelmara Mendes - Kırch,Guilherme (2015), " Determinants Of Financial Literacy: Analysis Of The Influence of Socioeconomic and Demographic Variables”, Revista Contabilidade \& Finanças, vol.26, n.69, pp.362377.

Rizwan, Mahammad- Sadhik, Mahammad - Kumar, K.S. Kishan (2015), “ A Study On Financial Literacy Among The College Students With Special Reference To Jnana Jyothı Financial Literacy Trust", 2ND International Conference on Science, Technology and Management, pp:730-735.

Shaari, Noor Azizah- Hasan, Nurfadhilah Abu- Mohamed, Ramesh Kumar Moona Haji Sabri Mior Ahmad Jafri Md. (2013), “ Financial Literacy: A Study Among The University Students”, Interdisciplinary Journal of Contemporary Research in Business, Vol 5, No:2, pp. 279-299.

Teb (Türkiye Ekonomi Bankası), (2012), "Finansal Okuryazarlık ve Erişim Endeksi”, İstanbul. 
Temizel, Fatih - Bayram, Fatih (2011), “Finansal Okuryazarlık: Anadolu Üniversitesi İktisadi İdari Bilimler Fakültesi (İ̈BF) Öğrencilerine Yönelik Bir Araştırma”, C.Ü. İktisadi ve İdari Bilimler Dergisi, Cilt 12, Sayı 1, ss. 73-86.

Thapa, Bharat Singh And Nepal, Surendra Raj (2015), "Financial Literacy İn Nepal: A Survey Analysis From College Students”, NRB Economic Review, 27 (1), pp:49-74.

Worthington, Andrew C. (2006), "Predicting Financial Literacy in Australia”, Financial Services Review, 15(1), pp. 59-79. 